\title{
MOOCs: Hope and Hype in Viral Technologies and Policies
}

\author{
Maureen W. McClurea,* \\ ${ }^{a}$ University of Pittsburgh, USA
}

\begin{abstract}
Massive open online courses (MOOCs) have emerged in the last couple of years as Internet-based vehicles providing low cost global access to quality education. They come in two basic forms: expert and self-organizing. The dominant expert model provides access to expertise through centralized software platforms with expert-designed short lecture videos, free online reading materials, discussion forums and a strong emphasis on measurable assessments. Self-organizing models focus on problems that may be too new for well-developed expertise, but are too important to ignore. Their rapid (viral) growth has resulted in related "viral policies" created by administrators and others who feel under competitive pressure to act quickly. MOOC interest is growing in many countries, opening new opportunities for international education partnerships. Backlashes have taken the form of: (a) unresolved problems with course perseverance, (b) assessment procedures to reduce cheating and improve peer review, and (c) faculty resistance to viral governance. While low course completion rates remains problematic, rapidly developing technologies and competitive networks are likely to influence higher education institutional policy for some time to come.
\end{abstract}

\begin{abstract}
Abstrak
Dalam beberapa tahun terakhir ini, massive open online courses (MOOCs) semakin populer sebagai sarana berbasis internet yang menyajikan akses global berbiaya murah untuk mendapatkan pendidikan berkualitas. Ada dua macam MOOC, yaitu expert dan self-organizing. Model MOOC expert menyajikan materi suatu bidang keahlian melalui platform perangkat lunak terpusat, dengan menyajikan video kuliah pendek, materi bacaan online, forum diskusi, dengan diikuti penekanan pada evaluasi yang terukur. Model self-organizing mengutamakan masalah-masalah yang mungkin baru bagi bidang yang sudah berkembang pesat, tetapi juga tidak dapat diabaikan begitu saja. Perkembangan MOOC yang maju pesat telah mengakibatkan banyaknya kebijakan cepat yang dibuat oleh para pengelola pendidikan yang merasa tertekan oleh persaingan dan harus bertindak cepat. Minat terhadap MOOC terus berkembang di banyak negara, sehingga membuka kesempatan kerjasama internasional di bidang pendidikan. Beberapa reaksi penolakan yang muncul dalam bentuk (a) tidak diselesaikannya permasalahan yang terkait kelanjutan perkuliahan, (b) prosedur asesmen untuk mengurangi kecurangan dan memperbaiki peer review, dan (c) penolakan staff pengajar atas tata kelola online (viral). Walaupun tingkat keberhasilan kuliah online masih rendah, perkembangan teknologi dan jaringan pendidikan yang makin kompetitif masih akan berpengaruh pada penentuan kebijakan kelembagaan pendidikan tinggi pada masa-masa yang akan datang.
\end{abstract}

Key Words: Massive Open Online Courses, MOOCs, Higher Education, Viral Technologies, Viral Policies

* Corresponding author.

Address: University of Pittsburgh, 5711 Wesley

W. Posvar Hall, Pittsburgh, PA 15260, USA.

Email:mmcclure@pitt.edu. 


\section{Introduction}

A massive open online course (MOOC) is an online course aiming at large-scale interactive participation and open access via the web. In addition to traditional course materials such as videos, readings, and problem sets, MOOCs provide interactive user forums that build communities for students, professors, and teaching assistants. MOOCs are a recent development in distance education (Wikipedia 2013).

The New York Times called 2012 "The Year of the MOOC" (Pappano 2012). Grabbing media interest early in the year, elite schools with star professors teaching courses that were free to everyone proved to be a compelling story. It set off a firestorm of interest in the media, unsettling university managers globally as they calculated the risks of institutional participation, driving them, trustees and politicians into the arms of vendors they didn't know. A strong sense of urgency also pushed partnerships with long standing rivals. Adding to the fray were developers and venture capitalists who wanted in, from universities and technology vendors to the Gates Foundation (Fain 2012; Forsythe 2013; Gelembjuk 2013).

It is almost as if there is an arms race in online education. Which MOOC platform can expand the fastest? Place your bets now (Empson 2012).

The business plan sounded odd: create a freestanding online course taught by a star professor. It would be expensive to create and maintain, but it would be given away for free to anyone in the world. During 2012, the general consensus was that although not much money was flowing yet, creating large global information distribution systems of people willing to work through elite institution courses would have payoffs in the longer term, as Stewart E. Sutin (2012), former head of International Banking at the Bank of New York Mellon, remarked.

But one thing is clear: If millions of consumers jump on board, the hosts will figure out ways to monetize via advertising or cross selling other products. Exactly what the participating universities will derive will be evidenced over time (Sutin 2012).

For senior managers, these are complicated, high risk, high reward games under conditions of significant uncertainty. Get in early and one might dominate the market or quite publicly crash. Get in late and the costs of entry may have become too high. Even a strategy of delay may be costly. Or should one sit out a technology bubble and wait to look good later?

MOOCs are a series of grand experiments in low cost global access to quality online education. They are not yet well defined because they are still being invented. MOOCs are an example of "viral policies." Viral technologies are new technologies that can disrupt institutions with simultaneous high potential reward and competitive risk (Daniel 2012). Policymakers and administrators may decide they are compelled to act, even in the face of high levels of uncertainty, because doing nothing is deemed to be even riskier than some action. MOOCs may cause a "bandwagon effect" where institutions jump rapidly into similar actions despite possible reservations (Jaschik 2013; Sharma 2013).

On one hand, MOOCs can be risky because little empirical evidence exists to support strategic institutional decision-making. On the other hand, there is perceived intense, time-critical competition across elite institutions internationally as they vie for the best students. While MOOCs contain high levels of uncertainty, they are too important to be ignored.

For example, MOOCs are creating whole new classes of partners and competitors for universities. New partners include: (a) small startup technology vendors (e.g., Coursera, Udacity, edX, Meetup, etc.); (b) large e-book vendors (e.g., Amazon); (c) vast new audiences of potential students globally; (d) rival universities; (e) major textbook publishers (e.g., McMillan) (Howard 2012); and (f) future employers. Competitors include: (a) self-organizing MOOCs that do not require expensive universities or courseware; (b) non-university educators such as museums, private firms, governments, international agencies and universities in other networks globally; and (c) universities' own faculty members working elsewhere parttime. The field is rife with opportunities and hazards.

This paper explores the fog of MOOCs and their contested terrain. It is a lively world filled with assumptions and innovations, a place where polities, 
philosophies, economies and cultures collide. In other words, it is a very exciting place to be. It briefly sketches the contested terrain found in each of its compositional words. It assesses costs and benefits for the key players, and calls for more studied consideration of this highly complex emerging field.

\section{What Makes a MOOC a MOOC?}

Each of the contested terms that comprise a MOOC and some of their interpretations will be discussed. What started out as relatively self-evident definitions have become blurred (Downes 2013a, 2013b, 2013c).

\section{Massive}

How massive is "massive"? No consensus definition exists yet. Does it mean too large to fit on a traditional campus? Over 5,000 students? Does it require a global network of specialists in order to create a threshold number for useful discussions? On one hand Sebastian Thrun's and Peter Norvig's "Introduction to Artificial Intelligence" computer science course at Stanford in the fall of 2011 enrolled 160,000 globally. When the students realized the enormity of the venture, many volunteers translated materials into 40 different languages. The delighted faculty automated as much as they could at the time (Stevens 2012). This launched MOOC fever. Thrun designed a new startup company, Udacity, soon afterwards.

Stephen Downes, a leading Canadian MOOC designer took a different path, stating that learning occurred through talking. For him, MOOCs were about the discourse of social networks working best through a great deal of peer interaction. His response to the best MOOC size question was surprisingly small, about 800 (2008).

In addition, variants on the concept of massive have been formulated. For example, LOOCs are "little" MOOCs with less than several hundred students (Kolowich 2012). "Small" has been ascribed to courses that are both small and "private," and therefore not "open" to all. These are called SPOCs, or Small Private Online Courses (Rivard 2013a).

\section{Open}

What does "open" mean? For many it is equated with free, but that is not entirely accurate. Open has many interpretations, and a more central one means "accessible" (Vander Ark 2012). In the case of MOOCs, access to a technology infrastructure is central (hardware, software, bandwidth, skills, etc.). Accessible can also mean affordable. For example, most MOOCs are generally free, but credentialing may have a price. For example, MOOCs may rely on free materials, but recommended supplemental materials and credentialing may be not be free (Spinner 2013). More recently some MOOCs have started shifting material prices from free to low cost (Downes 2013b, 2013c).

\section{Online}

All MOOCs are online, of course, but what that means remains murky. Early MOOCs attracted many who already had skills in instructional technology and design. Thrun and Norvig greatly extended the MOOC audience by automating much of their "Artificial Intelligence" course (Stevens 2012). This led to the rapid rise of course software with platforms that provided convenient access for less technically-inclined faculty and students.

\section{Course}

MOOCs have been developing along two different lines: expert and self-organizing, based on philosophical, technological and pedagogical views, as well as access to resources. Most of the MOOCs related to higher education institutions are expert MOOCs (Daniel 2012; Oram 2012; Wikipedia 2013).

Expert MOOCs (xMOOCs) often follow traditional lecture structures with videos of professors lecturing to a live audience. Some online students liked seeing the professors face-to-face with students because it gave them a deeper sense of participation (Coursera 2013). Most are intended to build measurable skills, often those sought after in the technology industry. 
xMOOCs tend to use highly centralized Learning Management Systems (LMS) technology platforms to create ease of access to high quality content and expertise. These centralized platforms often combine the functions of more traditional LMS, such as Blackboard, with large scale, social networking features. There is an emphasis on short, well-structured video lectures (similar to the Khan Academy), discussion groups and automated quizzes. The courses have clear beginnings and endings (Coursera 2013; edX 2013).

xMOOCs emphasize individual students building common skills and require a high degree of centralization and control of materials and assignments aligned with instructional standards. These centralized software platforms build on more traditional models of pedagogy, assuming some of the best learning happens in the presence of faculty members who are skilled and experienced in the area being studied. Here the emphasis is on building human capital knowledge and skills, with the development of social learning networks embedded in the course during the time that it is offered. Social networks, which continue after the course ends, were initially considered to be pleasant but tangential outcomes (Coursera 2013; edX 2013). This began to change when Coursera students organized local "meet ups" on a regular basis. This allowed students in courses to meet locally and continue the social networking after the course ended, extending it to employment and goals (Meetup Coursera 2013).

Most xMOOCs are likely to have the following characteristics (McClure 2013):

- multiple levels of participation (e.g., visitor, participant, completer, master);

- automated registration systems;

- access to extensive pre-selected required and recommended materials;

- automated discussion group generators;

- use of designated groups for learning support;

- multiple short videos focused on primary concepts and messages;

- intelligent tutors embedded in the videos so that both professors and students can quickly check their understanding of the material;
- automated quizzes and exams (74 percent of MOOCs in a survey of experienced professors) (Kolowich 2013b);

- some MOOC providers partnered with testing companies to support certification through the online proctoring of exams, identity verification using webcam and keystroke monitoring (e.g., ProctorU, Signature Track, etc.) (Eisenberg 2013);

- most courses are not offered for credit, but the American Council on Education (ACE) has nationally certified courses for acceptance for college credits, and some colleges and universities have stated they will accept them (e.g., Antioch, San Jose State). ACE has no legal credentialing authority, as it is primarily a state function (Roach 2012; Fain 2013; Kolowich 2013a);

- may work best currently in stable or highly segmented environments (introductory or remedial courses or advanced courses for enrichment); and

- intellectual property rights are blurring across private companies, universities and faculty members. Contracts are trying to sort this out. For example, some platform providers do not allow remixing and repurposing course materials. Institutions are responsible for copyright clearances (Peralta 2012). Proceed with caution.

\section{Expert MOOCs}

As of the spring 2013, the major providers related to university networks included Coursera, edX and Udacity (Kolowich 2013b). The Khan Academy is somewhat related (MOOC Map 2013). Their partnerships are forming new networks for universities and their faculty members.

Coursera is the largest and most visible MOOC provider. The startup was founded in 2012 by Stanford University computer science professors Andre Ng and Daphne Koller. The company has attracted 83 global partner universities, museums and NGOs. Almost four million students enrolled in its 390 courses as of 24 June 2013 (Coursera 2013). 
Coursera provides a collection of courses based on partners' selections of star faculty members. Institutional partners bear course production cost estimates ranging from US\$15,000 to US\$100,000, far less than edX. There appears to be no curricular or focused institutional strategy. It appears to just grow.

This growth strategy may or may not backfire by "diluting the brand" with too many players in what was originally posed as an exclusive game. It depends in part on the scale of its potential reach. New partners added to Coursera's blog page on 29 May 2013 included a number of US public university systems: (a) the State University of New York (SUNY), (b) Tennessee Board of Regents, (c) University of Tennessee System, (d) University of Colorado System, (e) University of Houston System, (f) University of Kentucky, (g) University of Nebraska, (h) University of New Mexico, (i) University System of Georgia, and (j) West Virginia University.

edX is smaller than Coursera, has a more focused reputational strategy in building global partners, and is currently more intensely capitalized. Harvard and MIT each invested roughly US $\$ 30$ million. They now have about 20 courses available. edX's current president is Anar Argarwal, an MIT professor and computer chip designer. It has grown strategically, building on institutional reputation and partnering with strong universities internationally. edX invests heavily in course design, charging US $\$ 250,000$ per course for significant assistance to its own partners for course development (Kolowich 2013c).

Beginning with MIT and Harvard, edX has added only 26 formidable global partners in key strategic markets. As of 23 June 2013, they included: (a) the Australian National University, (b) Berkeley, (c) Berklee College of Music, (d) Boston University, (e) Cornell University, (f) Davidson College, (g) Delft University of Technology, (h) École Polytechnique Federale de Lausanne in Switzerland, (i) Georgetown University, (j) the Hong Kong University of Science and Technology, (k) IIT Bombay, (l) Karolinska Instituet, (m) Kyoto University, (n) McGill University, (o) Peking University, (p) Rice University, (q) Seoul National University, (r) Technische Universitat Munchen, (s) Tsinghua University, (t) the University of Queensland, (u) Wellesley College, (v) University of Texas System, (w) University of Hong Kong, (x) Universite Catholic de Louvain, (y) the University of Toronto, and (z) the University of Washington. The edX platform is designed for both online and blended courses (edX 2013; Maslen 2013).

Udacity is a private startup company founded by Stanford research professor Sebastian Thrun, who led Google's DARPA Grand Challenge team to its first win ever with Stanley, a self-driving car. His "Artificial Intelligence" course with Peter Norvig launched the xMOOCs movement with 160,000 students (Stevens 2012). So far Udacity has the most focused strategy, centering on STEM subjects (science, technology, engineering, and mathematics) and related business courses. These can be adapted to automation and can build employment skills.

Using a vertical integration strategy, Udacity stayed focused on employer needs. Originally focused on linking students and individual professors with high tech employers, while skipping the university as middleman, more recently it branched out into developmental mathematics courses (and a psychology course) through a partnership with San Jose State. Udacity stuck to a defined curriculum strategy based on instructional difficulty. Courses may build in a sequence and are rated as beginner, intermediate or advanced (Udacity 2013).

In addition, MOOC networks are rapidly globalizing. The implications of these new networks on education, economic and political development has yet to be understood. Established in December of 2012, FutureLearn LTD, a UK-based initiative launched in partnership with: (a) Cardiff University, (b) King's College, (c) Lancaster University, (d) the Open University, (e) University of Birmingham; (f) University of Bristol, (g) University of East Anglia, (h) University of Exeter, (i) University of Leeds, (j) University of London, (k) University of St. Andrews, (l) University of Southampton, and (m) University of Warwick (Paar 2012; Watters, 2012). Since then it has added, as of 24 June 2013: (n) the British Council, (o) the British Library, (p) the British Museum, (q) University of Bath, (r) University of Edinburgh, (s) University of Glasgow, (t) University of Leicester, (u) Loughborough University, 
(v) Monash University, (w) University of Nottingham, (x) Queen's University of Belfast, (y) University of Reading, ( $\mathrm{z}$ ) the University of Sheffield, (aa) University of Strathclyde, and (ab) Trinity College Dublin. In the first six months of 2013, MOOC university partnership growth was explosive.

\section{Self-Organizing MOOCs}

Unlike xMOOCs grounded in technology, self-organizing MOOCs (cMOOCs) are grounded in pedagogy. cMOOC inventors include Canadians Stephen Downes, Dave Cormier (who coined the term "MOOC") and George Siemens (Cormier 2012; Siemens 2012a).

cMOOCs are designed around a "connective" pedagogy that helps people develop in an Internet environment. The Internet is unlike most expert classrooms in that the driving force is overwhelming amounts of information. People need to prioritize quickly and respond with the Internet tools they have on hand at the time. While expert MOOCs work hard to reduce uncertainty by regulating learning materials and processes in the classroom using LMS, cMOOCs pattern their classrooms to mimic the Internet, under the assumption that students need to learn how to learn on their own in highly unstructured and uncertain worlds.

This approach requires a high degree of tolerance for ambiguity and a lack of structure because courses are built on the decentralized platforms of students' everyday technology, and not on highly centralized LMS. Students design their responses and own and keep their work on their own platforms. These don't go away at the end of a course, as in an LMS.

cMOOCs do not rely on single, centralized and proprietary LMS platforms. These low cost approaches are based on students' "lived experience." Responses to courses are expected to emerge from their everyday lives. Responses to student assignments thus need to be created out of their Internet experiences with Facebook, Twitter, Instagram, and many other platforms that change rapidly (Mak 2012). One strength of this approach is that students are self-taught and bring these skills to the course (Siemens 2012b).
This decentralized approach allows cMOOCs to be light, flexible and relatively inexpensive to run globally. For example, UNESCO has used this model in order to reach resource poor environments (MobiMOOC 2012).

cMOOCs focus on learning less through short video lectures and automated quizzes, and more through peer dialogue and the support of diverse communities. Materials are less prescribed as both faculty and students take responsibility for discovering, remixing and re-purposing open, public resources culled under conditions of information overload found in everyday life (Siemens 2012a, 2012b). One intention of this approach to learning is to form networks, because the pedagogy is framed in terms of human relationships not software platforms.

These MOOCs are based on learning theories that view "good" education as agency-based and context embedded. This means that students learn by building on what they already know within a familiar environment. Students learn by talking, not only with the course instructors, but also with each other, as it gives them opportunities to rethink and reframe what they are learning. Assessments and credentialing are important, and community building is considered is to be central (Siemens 2010b).

\section{MOOCs, Viral Technology, Ideas and Policies: Warp Speed}

Google Trends, Google Scholar and Google's searchable languages all point to the very rapid growth of MOOC infrastructures. Figure 1 shows how the search term MOOC "Massive Open Online Course" trended in Google Trends over the past 52 weeks as of May 2013. Google Trends measure the relative frequency of search terms through an indicator called "search interest." It ranges from 0-100, where 0 is no search interest and 100 is "peak search interest." Google aggregates searches weekly. The $\mathrm{x}$-axis refers to the 52 weeks between May 2012 and May 2013. The y-axis refers to an indicator of the use of the term MOOC in search queries across languages. In May 2012, search interest was close to zero. By May 2013, however, it peaked at 100, the highest score possible (Google Trends 2013). 
Interest in MOOCs went viral rapidly. One measure of global interest can be found in translations. Within only a year since the launching of key startups such as Coursera, edX, and Udacity, virtually all of Google's searchable languages had at least one search result for MOOCs (see Table 1).

Table 1. MOOCs Gone Viral
1. Afrikaans
2. Arabic
3. Armenian
4. Belarusian
5. Bulgarian
6. Catalan
7. Chinese (Simplified)
8. Chinese (Traditional)
9. Croatian
10. Czech
11. Danish
12. Dutch
13. English
15. Filipino
17. German
19. Hebrew
21. Icelandic
14. Estonian
16. French
18. Greek
20. Hungarian
22. Indonesian
23. Italian
25. Korean
24. Japanese
26. Lithuanian
27. Latvian
28. Norwegian
30. Portuguese
32. Russian
34. Slovak
36. Spanish
38. Swedish
40. Turkish
42. Vietnamese

At least one readable mention of MOOCs in Google's searchable languages. Source: Google (May 2013).

\section{MOOCs: Research in Highly Fluid Conditions}

How can researchers both adjust to this blistering pace, yet maintain their scholarly integrity? More traditional means of text-based research, and the use of refereed print journals, for example, have difficulty keeping pace with the speed of innovation. MOOC research needs to be conducted primarily online and rapidly disseminated. New forms and ideas can alter the field within weeks, rendering some of last month's work obsolete. The field is not only growing rapidly, but much more importantly, it is morphing rapidly into new structures.

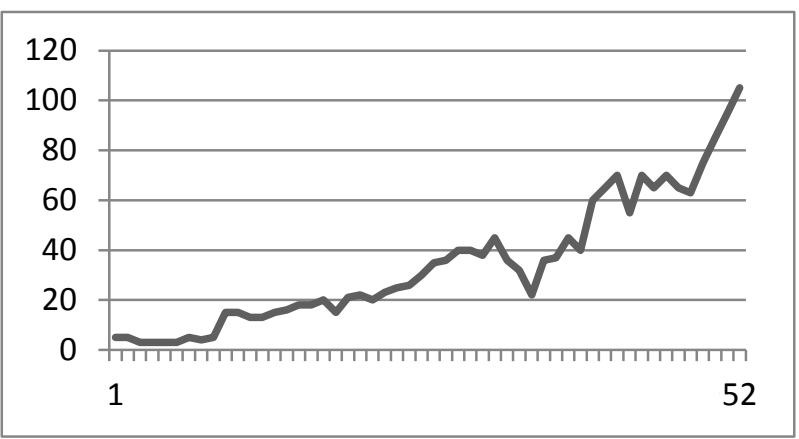

Figure 1. MOOC Trends (52 Weeks from May 2012 to May 2013). Source: Google Trends (2012).

A Google Scholar search by year (see Figure 2), yielded relatively few entries, compared with general media coverage, but did show growing interest. Even though the Google Scholar counts aren't all that accurate, they did indicate exponential growth. Please note that here the search was for MOOC "massive open online" course because some people referred to "massive open online education."

Thus there is an increasingly heavy reliance on contemporary littérature grise in online newspapers such as The Chronicle of Higher Education, as well as LinkedIn discussion groups, blogs, Wikipedia and YouTube videos. As some of these sources were somewhat less reliable, more effort than usual was needed for triangulation.

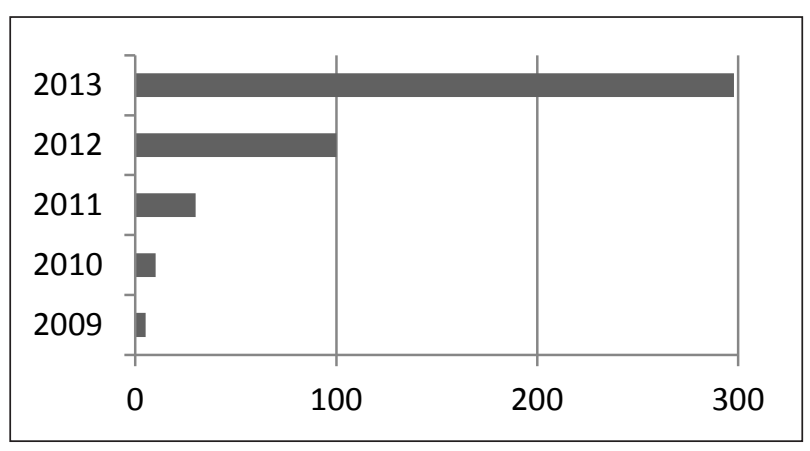

Figure 2. Google Scholar Search: MOOC "Massive Open Online: Course. Source: Google Scholar (2013).

Additionally, some researchers are immersing themselves in the MOOC experience in order to better understand them (Kischner 2012; McCracken 2012; McClure 2013). 
Costs and Benefits: Students, Academic and Technology Providers

Cost and benefit structures differ across students, faculty members and higher education institutions. What may be a free course for students may turn out to be somewhat expensive for universities and a potential windfall for private platform providers (Bates 2013).

\section{Students}

Student benefits are multiple. Most MOOCs are still free. Students can sign up, find all the resources that they need online, and complete all of the assignments at no cost. They can receive course credit, and, barring that, perhaps a certificate of completion or a badge. The reason for free MOOCs is regularly announced by many of the key players, notably edX, Coursera and Udacity, to be a way of extending access to an elite education to those who might not otherwise have it. MIT led the way beginning in 1999 with a US foundations-sponsored initiative to design OpenCourseWare that provided access to MIT's open, online educational resources in course materials.

In addition to their relatively low per capita LMS costs, the new platform technologies of MOOCs provide other benefits to students. They are 100 percent online, so students can take courses anywhere in the world. Different tracks are available to students, depending on their commitment levels. This provides greater flexibility than in traditional residential courses. The introduction of social networks permits social learning on a global scale.

There are, however, a growing number of options that carry costs for students. The most important centers the issue of credentialing. Credentialing can take a number of forms. Most students currently do not take MOOCs for credentials. For those individuals who want some sort of credential, several tracks may be provided for a fee. The more complex the assessment is, the more expensive the fee. There can be additional monitoring costs to reduce cheating. Supplemental materials may carry costs. Quality may be high now, but there are still problems. What will the addition of partners with fewer resources to invest mean to the longer-term value of course completion?

\section{Academic Providers}

Elite research universities have a structural dilemma in terms of costs and benefits. Will growth in one area strengthen or weaken growth in other parts of the university (Tucker 2012)? They produce knowledge, which is generally a public good. As a counterweight they privatize access to teaching, usually by limiting it to residential campuses. With the encroachment of MOOC technology, many see making much more money by building their global brand through online teaching, and dominating the market through a winner-take-all strategy based on exclusive comparative advantage. MOOC platforms promise to deliver on this approach, perhaps by substituting brand recognition for course quality (Uvalic- Trumbic 2013). According to Simon Marginson (2012, 10-12):

The MOOC paradigm disrupts normal higher education [through its] open access [to] knowledge from institutions that charge up to [US\$50,000] per student per year: this reflects the fact that knowledge is a "public good." It is non-rivalrous and non-excludable. As the late Elinor Ostrom said in her 2009 Nobel prize lecture: "Public goods are both non-excludable (impossible to keep those who have not paid for a good from consuming it) and non-rivalrous (whatever individual A consumes does not limit the consumption by others)."

On one hand, when teaching can be restricted to residential campuses, knowledge can at least be somewhat contained, so that those who have paid high prices are guaranteed some level exclusivity. On the other hand, elite university "brands" could overwhelmingly dominate a massive MOOC market. Marginson (2012) continues:

Open courseware has the same logic as the winner- take-all markets in celebrity actors or top 
movies or music discussed by Cornell sociologist Robert Frank. A tiny handful of producers and products dominate the global market, overwhelmingly. There is only one Elvis, and only one Harvard.

MOOCs have been repeatedly described as a disruptive technology. While this may be somewhat true, don't overlook the value of social networks emanating from residential programs. At greater risk then may be residential and online higher education institutions without elite reputations and extensive alumni networks able to mobilize considerable social capital. Low cost MOOC technologies could displace upwards, starting with the institutions or courses with the weakest reputations.

Clayton Christensen, a professor of business administration at Harvard Business School is known for his theory of "disruptive innovation" in business, which holds that upstart challengers usually displace market incumbents by first establishing a toehold with low-cost products in markets that the incumbents are willing to cede. Over time, the challengers manage to increase quality while still keeping costs low, taking over successively higher-margin markets until they finally dominate the market as a whole.

This pattern has played out in the steel industry, in the automotive industry, in the computer industry - and is now playing out in the cellphone industry. But...it has never occurred in the hotel industry, because challengers cannot compete for high-margin business without adopting the cost model of the incumbents: if Holiday Inn wants to compete against Ritz-Carlton, it has no choice but to hire concierges and put in marble floors. What challengers in the hotel industry lack, he said, is an "extendable core," a new technological approach that can be steadily improved at low cost.

Higher education has been in the same boat... until now. The suite of technologies that edX and others have introduced-video lectures, online discussion boards... and the like - constitute education's extendable core. These technologies are now in their infancy, but like the steel produced in "mini mills" that displaced integrated steel mills, they will only improve in quality. (Hardesty 2013)

\section{Assessing Costs and Benefits}

Academic costs can be measured in many ways, such as preparation, distribution, implementation, assessment and sustainability costs. Others are less tangible and include the contribution of MOOCs to the institution's mission and value of its reputation in terms of its "goodwill" or "brand."

\section{Preparation Costs}

Preparation costs for MOOCs vary widely. A survey in The Chronicle of Higher Education of professors who taught MOOCs estimated their preparation time costs averaged more than 100 hours per course. Who pays for this and what is their return on inves ment? Universities are charged with creating MOOC-content themselves (Kolowich 2013b). Administrative investment in course design ranges from blatantly minimal to US $\$ 250,000$ in up-front costs for edX studio support. Where will the money come from, residential tuitions?

\section{Distribution Costs}

Distribution costs vary widely. Internet access costs are relatively low in many target countries, so it is not a major factor in most places. Distribution costs are high because of partnership costs with platform providers. The platform providers can potentially charge high fees, but revenue streams are still quite small, so the unbalanced contract returns have yet to be felt. Under Coursera's contracts, for example, partners keep only 6 percent to 15 percent of the revenue, and 20 percent of the gross profits (Anderson 2012). Academic providers may not be happy later if MOOC revenues begin to generate large profits, say for credentialing.

\section{Implementation Costs}

Implementation costs vary depending in part on the available support staff. A survey in The Chronicle of 
Higher Education revealed that the median MOOC professor only had one teaching assistant assigned to the course (Kolowich 2013b). MOOC professors were not paid by enrollment, and currently do not receive significant additional compensation. If revenues expand, however, implementation costs are also likely to rise. Declining or uneven course quality may affect all network partners by devaluing the brand.

\section{Assessment Costs}

Assessment costs are mixed. Automated quizzes and exams, particularly for mathematics, science and technology courses that are amenable to automation, can generate relatively low costs. Studentbased peer reviews can also offset assessment costs, making them relatively low for the institution. Some new technology companies, such as Signature Track, manage online assessments for a fee that can be offloaded to students seeking credentials (Coursera Blog 2013). Coursera offered proctored exams at the end of courses through ProctorU, an online proctoring service that connects exam monitors and students via webcam. The service costs from US\$60 to US\$90 (Eisenberg 2013).

Also, the introduction of additional teaching assistants and professorial time can raise costs significantly. The Chronicle of Higher Education survey, however, reported the average number of teaching assistants per MOOC course was only one. In a highly automatable course, this might work, but it is unlikely to work in most other courses because of the need to field questions as well as monitor discussions and peer review.

\section{Sustainability Costs}

Sustainability costs for expert MOOCs are largely unknown at this point. On one hand, cMOOCs have adopted a low cost strategy of multi-platform, personal and highly flexible responses. On the other hand, xMOOCs have adopted more centralized, expertise-based and standards assessed models that require greater institutional support and maintenance. Sustainability is a major unknown in the future of MOOCs, because without revenue streams, "game changers" fade into fads. A lack of capitalization leading to lower quality MOOCs among some of the partners can taint the network brand. Undercapitalization is likely to remain a chronic problem.

\section{Faculty Benefits}

It is important to note that MOOCs were created not by startup companies, but by a small group of academics looking to do a better job teaching. When asked them what drew them to MOOCs, 71 percent said they wanted to increase access to higher education. Of the MOOC professors surveyed, ownership was clear, as 73.3 percent said they owned intellectual property rights for content they produced. Once launched, many found the experience exhilarating. As one Duke professor, Sinnott-Armstrong, said:

I've got almost a million downloads of my videos already. I mean, c'mon. That's just amazing! This is over 20 times as many students as I would reach in my career. ("Duke Professor" 2013)

\section{Academic Institutional Benefits}

For the most elite universities, the pull of the global brand is quite real. Students and resources flow into and through them from across the world. Extending their global brand allows them both to attract and recruit top students, and to increase the value of the institution itself, improving their competitive position not only in teaching but in other revenue generating areas such as research, publishing houses, alumni donations and licensed logo wear.

\section{Technology Provider Benefits}

As one might expect, technology providers started out being costs in search of benefits, as the technology looked for uses. In the first half of 2012, startups took a "build it and they will come" approach to generating revenue. Most of the financial efforts went into the initial capitalization needed to launch. As stated earlier, edX launched in the spring of 2012 with US\$60 million: US\$30 million each from MIT and Harvard ("MIT and Harvard" 2012). 
Less well funded, but offering about the same number of courses, Udacity had raised a little over US\$20 million by the fall of 2012. Coursera launched in the spring with US\$16 million and grew exponentially with only about US\$20 million in startup funding, and leveraged growth; academic partners are responsible for creating their own courses (Watters 2012). Coursera may be somewhat vulnerable due to an apparent lack of capital. They have adopted an aggressive growth strategy that has been successful in the shorter term, but may pose problems for brand clarity later on.

Coursera, for example, currently earns from 85 percent to 94 percent of the revenue generated, and 80 percent of the gross revenue. "edX models offer higher shares to universities than agreements with Coursera do, but only once edX has collected its minimum payment." There is no minimum payment to Coursera, meaning universities are guaranteed a cut of any revenue for their MOOCs on Coursera, even if the company offers a smaller piece of the pie than edX does (Kolowich 2013c).

Providers also discussed a wide range of alternative potential revenue streams including:

- Semi-Credentialing. Rather than focus on degree credentials, the development of certificates or badges offered course completers something to put on their resume that employers would acknowledge (Crotty 2013).

- Employer Recruiting. Startups charged potential employers for access to student data through two options. First, Coursera and Udacityprovided direct recruitment access through the platform to corporate-student messaging and other opportunities. Second, it invited students to visit employers and take qualifying exams. "The company pays a flat fee to Coursera for each introduction, and the college offering the course gets a percentage of that revenue, typically between [six and fifteen percent]." Udacity said 350 companies had signed up for its job program (Young 2012).

- Academic Recruiting. Top Cornell professors claimed that when recruiting, the best students expected access to MOOCs that demonstrated the cutting edge environment they were seeking (Cornell 2012).

- E-Textbooks and Print Materials. On one hand, free courses imply free materials. But this may not cover recommended materials. A Princeton professor teaching a "World History" course during the fall 2012 to 80,000 students stated that the course could be taken without the discounted US\$90 print textbook he authored. It could, however, help enrich the course experience. Consider: if only 10 percent of his students bought the book, that would have been $8,000 \times$ US $\$ 90=$ US $\$ 720,000$. If the author earned roughly 11 percent of that, it would have been US\$79,200. Also, discounted etextbooks may have a bright future. Recently textbook publishers have entered a partnership on discounted materials provision (Price 2013).

- Paid Human Tutoring and Other Kinds of Personal Support. Tuition fees paid for offering online courses for credit on university campuses (e.g., Udacity and San Jose State) (Lewin and Markoff 2013).

\section{The Credentialing Turn}

In February 2013, the media narrative took a sharp turn toward offering courses that some colleges and universities could accept for transfer credit. It was rooted in the growing problem in the US of the high costs of higher education access. Coursera announced a foundation-sponsored tactical move to "disrupt" current expensive credentialing systems. The American Council on Education (ACE), together with the Bill and Melinda Gates Foundation, conducted an independent review and endorsed five courses offered through the Coursera platform to its 1800 member colleges and universities. Four were for undergraduate credit and one was approved for developmental math vocational credit (Algebra):

- "Algebra," University of California at Irvine;

- "Bioelectricity: A Quantitative Approach," Duke University;

- "Calculus: Single-Variable," University of Pennsylvania; 
- "Introduction to Genetics and Evolution,"Duke University; and

- "Pre-Calculus," University of California at Irvine. (Faine 2012)

ACE positioned itself to be the gatekeepers of the value of MOOCs to US higher education. The council received US\$3 million from the Bill and Melinda Gates Foundation to support its partner research efforts with the Association of Public and Land-grant Universities (APLU) and Ithaka S+R. ACE also studied how these courses could be used to improve access and college completion rates (Fain 2013; Kolowich 2013a). According to Fain (2013) this move clearly demonstrated "that traditional higher education (represented by ACE and APLU) and Gates, the primary force behind the national college 'completion agenda,' both believed in the disruptive potential of MOOCs."

\section{Global Infrastructure Development}

Students from India (8.8 percent) comprised the largest number of Coursera students outside of the US (27.7 percent) (Wikipedia 2013a). In a bold move, the Government of India incorporated the consideration of MOOCs in its 2012 infrastructure planning report in private education (Upadhyay and Maitra 2013). India has a long history of elite Institutes of Technology, as well as successful distance education programs for rural areas. This, combined with other educational capital and entrepreneurship, can serve as a guide for the development of technological infrastructure in both the public and private education sectors (deWaard 2012). As of 25 June 2013 IIT Bombay had joined edX.

In addition, many countries in South and Southeast Asia, as well as in Latin America and Southern Africa, have already made major investments in distance and online education and can build on that expertise and technological infrastructure (Sharma 2013). For example, a country with extensive experience in distance and online learning is Indonesia. While India's interests in rural education are driven by the sheer scale issues of size and population, Indonesia's interests in part rest on its status as an island nation
(Upadhyay and Maitra 2013). It is the world's fourth largest country in terms of population, with about 238 million people and over 17,000 islands, of which about 6,000 are inhabited (CIA 2013). Education across these islands is a continuing problem.

The Ministry of Education and Culture (MOEC) has at least three major sources for support. First, it supports the Universitas Terbuka (UT) or Open University, whose mission has been the support of distance and open learning since its founding in 1984 (Wikipedia 2013b). UT currently supports more than 500,000 students.

Second, there are new networks of universities that can provide additional course content, perhaps opening up new possibilities for partnerships such as the UK's FutureLearn. The Konsorsium Perguruan Tinggi Indonesia-Pittsburgh (KPTIP), for example, is a network of Indonesian universities with elite teacher education programs that has international partnerships for research and practice (KPTIP 2013).

One of KPTIP's international partnerships is with the University of Malang in East Java. It focuses on university-based laboratory schools. Malang's laboratory schools include a primary, a secondary and a specialized school for autistic children. The schools belong to an international network of university- based lab schools. Malang lab schools have a strong national reputation. They use master teachers (often university faculty members) who work with pre-service and in-service teachers, as well as with researchers, to continuously improve teaching programs and practices. A lab school MOOC could be based on Indonesian university research and experience. Together with their international partners, they could offer courses to pre-service and in-service teachers both nationally and beyond to those interested in the lab school movement (Rachmajanti and McClure 2011).

Third, the Indonesian Ministry of Education and Culture (MOEC) itself has considerable professional expertise and experience in supporting pre-service and providing service training. One chronic problem of the ministry is the rollout of new policies that require simultaneous implementation nationwide. Given their limited resources, ministry development 
of MOOCs in partnership with KPTIP for continuing professional development might help reduce the time needed for national training for policy and program implementation.

\section{Benefits of Blended Instruction}

In addition to online courses that are taken exclusively through distance education, another option for MOOC use is to blend them into existing courses. Students are already using MOOCs for supplemental development and enrichment. Instructors are using them to enrich their own courses. Some use them in "flipped classrooms" where students watch lectures for their homework and then work on problems and assignments in class, where problem-solving skills may be better monitored. Finally, the construction and maintenance of MOOCs can become course team projects (Riggs 2013).

\section{Backlash}

\section{Classroom Management Problems}

In addition to cheating and low completion rates, supervision of peer learning has been a continuing problem, as viewed regularly on LinkedIn blogs related to MOOCs, Coursera and other outlets. It is difficult to assess how widespread these problems are, though many have unsubstantiated opinions about them.

\section{Faculty Governance}

Most faculty members in Coursera's partnering universities had little inkling their institutions were jumping feet first into MOOCs (Azevedo 2012). Administrators argued, how could they not? Things were moving so fast, and the needs were so urgent, to wait may have been too late. For some in the academic community, these responses may have been seen as both practical and farsighted. The problem is that they are taking place outside of the university governance structure. The urgency to move quickly may be offset by longer-term needs to deliberate. Also, the efficiencies of curriculum standardization may overwhelm more important needs for student customization (Lane and Kinser 2012).

\section{Faculty Governance Problems}

What are the longer-term consequences? Have quick moving administrations set up the universities for short-term gains and long-term losses? As an example of the latter, a LinkedIn discussion cited David Noble's 1999 analogy to Kurt Vonnegut's Player Piano in his article "Digital Diploma Mills: The Automation of Higher Education" (2013):

In Kurt Vonnegut's classic novel Player Piano the ace machinist Rudy Hertz is flattered by the automation engineers who tell him his genius will be immortalized. They buy him a beer. They capture his skills on tape. Then they fire him. Today faculty are falling for the same tired line, that their brilliance will be broadcast online to millions. Perhaps, but without their further participation. Some skeptical faculty insist that what they do cannot possibly be automated, and they are right. But it will be automated anyway, whatever the loss in educational quality. Because education, again, is not what all this is about; it's about making money.

Beyond the reference, faculties from Amherst, San Jose State and others have raised cautions (Anderson 2013; Rivard 2013c). Some want to ensure better deliberation of the costs and consequences; others, because they see administrators cutting costs by replacing live faculty with virtual ones who can't offer students the same needed experiences. Other backlash issues have included the technical failures created by centralized structures trying to manage very largescale groups (Downes 2013b, 2013c; Talbert 2013).

\section{Conclusion: Now What?}

MOOCs are still in an experimental stage, as their technology, content, pedagogy and assessments are being invented at a speed generally unknown in many of today's universities (Ferenstein 2013). 
This is in part because the movement is being predominately driven by access to new technologies and their management. This could be problematic if MOOCs have become a viral policy supported by administrations without a deep understanding of their consequences in terms of sustainable costs and benefits.

The options are many and it is understandable why so many want to jump first and think later. It is not always a bad strategy. Prudent strategy at this point, however, would be to first understand where the university stands now relative to sustainable revenues, reputation and competitive risk. It then needs to design and assess options, and, if it invests resources, it should be with a reasonable understanding of both shorter and longer term risks and rewards. Investing in the future is prudent; investing resources that an institution cannot afford to lose would not be so. The risks are high, and so too are the possible rewards (Downes 2013c).

MOOCs are not for the faint-hearted. What then are some other early conclusions that can be drawn about MOOCs?

1. Ideas and technology that lead to "viral policies" can be complex to manage as the field is neither well defined nor well researched. Worse, it is highly contested, and the current hype does not acknowledge the relative risks.

2. With a solid strategy, there may be a large upside market due to: (a) significant potential to extend global reach, and (b) an ability to reach across the education sector to include K-12 schools, professional development and lifelong learning.

3. University-based technology startups continue to blur the boundaries between non-profit institutions and private companies. This can be good for the economy. It can also be hazardous to the core deliberative qualities of ancient academic institutions if inappropriate contracts are signed.

4. Strategic overreach due to undercapitalization may or may not be a potential problem, especially for underfunded initiatives with rapid expansion strategies. It may be less of a problem for more heavier capitalized companies like edX.

5. There are a wide variety of innovative revenue streams including employer partnerships, online materials sales and online tutoring.

6. The largest and most critical potential revenue source is, of course, credentials. Technology providers are plunging headlong into solutions to the primary credentialing problem for them: valid exams. New partnerships include use of surveillance technologies to monitor test takers and verify their identities. STEM subjects may be more conducive to automated quizzes. Also, testing might be more successful and less expensive in the shorter term. Employability will remain an important factor for providing incentives for completion.

7. Are MOOCs a disruptive technology? Perhaps, but not enough thought has been put into estimating more realistic mid to longerterm consequences. Hype and hope currently trump usable evidence. They can destabilize competent institutional management when trustees or politicians come down with MOOC fever. A larger disruptive question may be to what extent will they be a threat to private online universities like the University of Phoenix? Can they be used extensively to reduce higher education access costs or will they destabilize a system of large undergraduate courses serving as cash cows for smaller upper-level and graduate classes in many elite universities?

8. More research attention is needed to compare expert and self-organizing MOOCs. xMOOCs assume that structured management is necessary for service delivery. They are standards seeking, centralized, hierarchical, and institution-based. cMOOCs are instead highly decentralized, assume that controlled, highly structured autonomy may not be the best way to be efficient, and create networks of diverse peer-to-peer relationships. We need to better understand the costs and consequences of both of these choices. 


\section{References}

Anderson, Nick. 2012. "Elite Education for the Masses." The Washington Post, November 3.

Anderson, Nick. 2013. “As Amherst Rejects Online Lecture Model, Educators Ponder What's to Gain from Trend." The Washington Post, May 1.

Azevedo, Alisha. 2012. "In Colleges' Rush to Try MOOCs, Faculty Are Not Always in the Conversation." The Chronicle of Higher Education, September 26.

Bates, Tony. 2013. "Briefing on MOOCs for the Board of Governors." Online Learning and Distance Education Resources. Available online at: http://www.tonybates.ca; accessed February 2013.

Central Intelligence Agency (CIA). 2013. "Indonesia." In The World Factbook. Washington, DC: CIA Online Library.

Cornell University. 2012. "MOOCs and Online Learning at Cornell." Cornellcast. Available online at: http://www.cornell.edu/video/moocs-andonline-learning-atcornell; accessed 20 October 2013.

Cormier, David. 2010. "MOOC Definition." YouTube video. Available online at: http://www.you tube.com; accessed October 2012.

Coursera. 2013. Homepage. Available online at: https://www.coursera.org; accessed 23 June 2013. Coursera. 2013. "Introducing Signature Track." Coursera. Available online at: http://blog. coursera.org; accessed 23 June 2013.

Crotty, James Marshall. 2013. "Badges Lend Gravitas To Free Education Revolution." Forbes.Available online at: http://www.forbes.com; accessed 23 June 2013.

Daniel, Sir John. 2012. "Making Sense of MOOCs: Musing in a Maze of Paradox and Possibility." Academic Partnerships. Available online at: http://www.academicpartnerships.com/research/ white-papermaking-sense-of-moocs; accessed 1 March 2013.

de Waard, Inge Ignatia. 2012. "MOOC Benefits for International Learners-An Overview." Slideshare slideshow. Available online at: http://www.slideshare.net/ignatia/mooc-benefits-for-internationallearners-anoverview; accessed 24 October 2012.
Downes, Stephen. 2008. "MOOC and Mookies: The Connectivism \& Connective Knowledge Online Course." Paper presented at the eFest by Ellumninate, Aukland, New Zealand. Available online at: http://www.downes.ca/presentation/197; accessed 26 February 2013.

Downes, Stephen. 2010. "The Role of Open Educational Resources in Personal Learning." YouTube video. Available online at: http://www.youtube. com; accessed 10 November 2012.

Downes, Stephen. 2013a. "How NOT to Design a MOOC: The Disaster at Coursera and How to Fix It. Debbie Morrison." Online Learning Insights. Available online at: http://www.downes. ca/post/59928; accessed 8 February 2013.

Downes, Stephen. 2013b. "The Great Rebranding." Half an Hour. Available online at: http://halfan hour.blogspot.com; accessed 4 April 2013.

Downes, Stephen. 2013c. "Everything You Thought You Knew About MOOCs Could Be Wrong." Half an Hour. Available online at: http://halfan hour.blogspot.com; accessed 4 April 2013.

"Duke University Philosophy Professor Walter Sinnott-Armstrong Has 180,000 Students In MOOC." 2012. The Huffington Post, January 22. eduMOOC. 2011. "Online Learning Today... and Tomorrow." Available online at: https://sites. google.com/site/edumooc/home; accessed October 2012.

edX.org. 2013. EdX. Available online at: https:// www.edx.org; accessed October 2012.

Eisenberg, Anne. 2012. "Keeping an Eye on Online Test-Takers." The New York Times, March 2.

Empson, Rip. 2010. "Coursera Adds 29 Schools, 90 Courses and 3 New Languages to Its Online Learning Platform." TechCrunch. Available online at: http://techcrunch.com; accessed 12 May 2013.

Fain, Paul. 2012. "Establishment Opens Door for MOOCs." Inside Higher Ed. Available online at: http://www.insidehighered.com; accessed 2 March 2013.

Fain, Paul. 2013. "Udacity's Credit Path." Inside Higher Ed. Available online at: http://www. insidehighered.com/news/2013/01/16/; accessed 19 May 2013. 
Ferenstein, Gregory. 2013. “72\% of Professors Who Teach Online Courses Don't Think Their Students Deserve Credit." TechCrunch. Available online at: http://techcrunch.com; accessed 28 March 2013.

Forsythe, Giulia. 2013. "MOOC Giants-Coursera, edX-Add More University Partners, Expand Abroad." WiredAcademic. Available online at: http:/Www.wiredacademic.com; accessed 4 March 2013.

Gelembjuk, Roman. 2013. My Education Path. Available online at: http://myeducationpath.com/ providers; accessed 3 March 2013.

Hardesty, Larry. 2013. "Higher-Ed Leaders Meet to Discuss Future of Online Education." Online Learning and the Future of Residential Education. Available online at: http://onlinelearningsummit. org/news.html; accessed 6 March 2013.

Howard, Jennifer. 2012. "Publishers See Online Mega-Courses as Opportunity to Sell Textbooks." The Chronicle of Higher Education, September 17. Jaschik, Scott. 2013. "MOOC Skeptics at the Top." Inside Higher Ed. Available online at: http://www. insidehighered.com; accessed 10 May 2013.

Kirschner, Jennifer. 2012. "A Pioneer in Online Education Tries a MOOC." The Chronicle of Higher Education, October 1.

Kolowich, Steve. 2012. "MOOCs' Little Brother." Inside Higher Ed. Available online at: http:// www.insidehighered.com; accessed 1 May 2013.

Kolowich, Steve. 2103a. "American Council on Education Recommends 5 MOOCs for Credit." The Chronicle of Higher Education, February 7.

Kolowich, Steve. 2013b. "Professor Leaves a MOOC in Mid-Course in Dispute Over Teaching." The Chronicle of Higher Education, February 18.

Kolowich, Steve. 2013c. "How edX Plans to Earn, and Share, Revenue From Its Free Online Courses." The Chronicle of Higher Education, February 21.

Kolowich, Steve. 2013d. "The Minds Behind the MOOCs." The Chronicle of Higher Education, March 18.

Konsorsium Perguruan Tinggi Indonesia-Pittsburgh (KPTIP). 2013. History. Surakarta, Indonesia: KPTIP. Available online at: http://kptip.uns.ac.id; accessed 30 June 2013.
Lane, Jason and Kevin Kinser. 2012. "MOOCs and the McDonaldization of Global Higher Education." The Chronicle of Higher Education, September 28.

Lewin, Tamar and John Markoff. 2013. "California to Give Web Courses a Big Trial." The New York Times, January 15.

Mak, Sui Fai John. 2013. "Who Controls the World?" Learner Weblog: Education and Learning Weblog. Available online at: http:// suifaijohnmak.wordpress.com/welcome-to-thisblog-on-connectivism; accessed 17 May 2013.

Maslen, Geoff. 2013. "MOOCs Spread Around the edX and Coursera World." University World News, February 21.

Marginson, Simon. 2012. "Yes, MOOC is the Global Higher Education Game Changer." University World News, August 12.

McClure, Maureen W. 2013. "MOOCs: Efficiency Frameworks: Blurring Boundaries." Paper presented at the Annual Meeting of the Comparative and International Education Society (CIES), New Orleans, LA, March 14.

McCracken, Harry. 2012. "MOOC Brigade: What I Learned From Learning Online." Time, October 22.

Meetup Coursera. 2013. Available online at: http:// www.meetup.com/Coursera; accessed October 2012.

"MIT and Harvard announce edX." 2012. MITnews, May 2.

MOOC Guide. 2012. Available online at: http:// moocguide.wikispaces.com; accessed 24 October 2012.

MOOC Map. 2013. Available online at: https:// fbcdn-sphotos-g-a.akamaihd.net; accessed 23 June 2013.

Myklebust, Jan Petter. 2013. "First MOOCs for Denmark, European Universities Sign Up" University World News, April 21.

Noble, David F. 1998. "Digital Diploma Mills: The Automation of Higher Education." First Monday. Available online at: http://uncommonculture.org; accessed 27 February 2013.

Oram, Andy. 2012. "The MOOC Movement Is Notan Indicator of Educational Evolution." 
O'Reilly Radar. Available online at: http://radar. oreilly.com; accessed 17 December 2012.

Paar, Chris. 2012. "Open University Launches British MOOC Platform to Rival US Providers." Times Higher Education, December 14.

Pappano, Laura. 2012. "The Year of the MOOC." New York Times, November 4.

Peralta, Clarisse. 2012. "Online Courses Raise Intellectual Property Concerns." Stanford Daily, November 1.

Price, Gary. 2013. "New Partnerships: SAGE, Macmillan, Wiley, Cengage, and OUP Will Make Some Textbook Content Available For Free to Coursera Faculty, Students." Library Journal: Infodocket. Available online at: http://www. infodocket.com; accessed 23 June 2013.

Rachmajanti, Sri and Maureen W. McClure. 2011. "University-Affiliated Lab Schools: A Collaborative Partnership Between The University Of Pittsburgh's Falk School And the Universitas Negeri Malang Lab Schools." Excellence in Higher Education 2 (1): 11-20.

Riggs, Janet. 2013. "MOOCs, Flips, and Blends." The Huffington Post, January 31.

Rivard, Ry. 2013a. "Three's Company." Insider Higher Ed. Available online at: http://www. insidehighered.com; accessed 5 May 2013.

Rivard, Ry. 2013b. "Free to Profit." Inside Higher Ed. Available online at: http://www.insidehighered. com; accessed 14 April 2013.

Rivard, Ry. 2013c. "edX Rejected." Inside Higher Ed. Available online at: http:// www. insidehighered.com/2013/04/; accessed 24 April 2013.

Roach, Ronald. 2013. "Morgan State University Expected to be First HBCU to Announce MOOC Deal." Diverse Issues in Higher Education. Available online at: http://diverseeducation.com; accessed 3 December 2012.

Siemens, George. 2010a. “TEDX/NYED'. YouTube video. Available online at: http://www.youtube. com; accessed 12 November 2012.

Siemens, George. 2010b. "Connectivism: Socializing Open Learning." YouTube video. Available online at: http://www.youtube.com; accessed 28 February 2013.
Sharma, Yojana. 2013. "Asia's First MOOC Draws Students from Around the World." University World News, April 17.

Spinner, Andrew. 2013. "Analyzing MOOCs: A SWOT Analysis." Andrew Spinner Website. Available online at: http://andrewspinner. com/2013/02/05/analyzingmoocs-a-swot-analysis; accessed 8 February 2013.

Stevens, Catherine. "Online Education, Udacity, MOOC, Open Ed." YouTube video. Available online at: http://www.youtube.com; accessed 22 October 2012.

Sutin, Stewart E. 2012, July 30. Email to the author. Sutin is Clinical Professor of Higher Education Management at the University of Pittsburgh.

Talbert, Robert. 2013. "When MOOCs Melt Down." The Chronicle of Higher Education, February 19. Tucker, Marc. 2012. "The Rise of the MOOCs." Education Week. Available online at: http://blogs. edweek.org; accessed 1 March 2013.

Udacity. 2013. "Get Ahead with College Credit." Udacity. Available online at: https://www.udacity. com/collegecredit; accessed 2 May 2013.

UNESCO. 2013. "MobiMOOC: Using a Mobile MOOC to Increase Educational Quality for a Diversity of Learners through Dialogue and Ubiquity." UNESCO:ICT in Education. Available online at: http://www.unesco.org; accessed June 2013.

University of Rochester. 2012. "University of Rochester Joins Nine Other Universities to Explore For-Credit Online Education." University of Rochester. Available online at: http://www. rochester.edu; accessed October 2012.

Upadhyay, Manish and Amitra Maitra. 2013. "Educational Technology: Relevance and Possibilities for Education in India." India Infrastructure Report 2012: Private Sector Education. IDFC Foundation. London: Taylor Francis Group.

Uvalic-Trumbic, Stamenka. 2013. "MOOCs-Mistaking Brand For Quality?" University World News. February 6.

Vander Ark, Tom. 2012. "Sir John Daniel: Openness Rather Than Scale is MOOC Contribution." Education Week. Available online at: http://blogs. edweek.org/edweek; accessed 17 December 2012. 
Watters, Audrey. 2012. "Top Ed-Tech Trends of 2012: MOOCs." Hack Education. Available online at: http://hackeducation.com; accessed 6 February 2013.

"What You Need to Know about MOOCs." 2013. The Chronicle of Higher Education, July 1.

Wikipedia. 2013a. "Massive Open Online Course." Wikipedia.Available online at: http:// en.wikipedia .org/wiki/Massive_open_online_course; accessed 23 June 2013.

Wikipedia. 2013b. "Universitas Terbuka." Wikipedia. Available online at: http://en.wikipedia. org/wiki/Universitas_Terbuka; accessed 23 June 2013.

Young, Jeffrey R. 2012. "Providers of Free MOOCs Now Charge Employers for Access to Student Data." The Chronicle of Higher Education, December 4. 